\title{
EFFECT OF KANTAKARI MULA SIDDHA DUGHDA PARISHEK IN THE MANAGEMENT OF VATAJ ABHISYANDA
}

\section{Supriya Gangaram Patil}

Asst. Professor, Dept. Shalakyatantra, Kodoli, Kolhapur.

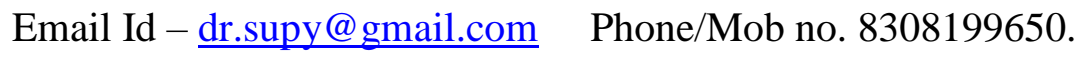

\section{ABSTRACT :-}

In this article we will see the effect of kantakari mula siddha dugdha parishek in vataj abhishyanda. Vataj abhishyanda is one of the sarvagat roga. According to modern ophthalmology vataj abhishyanda can be correlated with simple allergic conjunctivitis and also clinically with subacute form catarrhal conjunctivitis. Seka /Parisheka is one of the kriyakalpa in the treatment of ocular disease.So I have treated vataj abhishyanda one of the sarvagat roga with parisheka mentioned by sushrut in vataj abhishyanda chikitsa. Treatment for eye disorders has been explained under the heading of Kriya Kalpa and Seka is one of the Kriya kalpa. Medicine is poured on closed eyes (on closed eye lids) continuously from 4 anguli (4') height for specific time, according to dosha prakar.Parisheka is a synonym for seka. It is exclusive ayurvedic treatment with least complications as it is used externally.If parisheka is given according to dosha condition, then it can even cure the balwan dosha. A good appreciation from patient is received.Medicines used in seka reaches through Netra Sandhi , shirah,
Ghranendriyam, and their srotasam and performs urdhwajatrugata doshaprahar.

KEY WORDS: - Kantakari mula siddha dugdha,Vaataj

abhishyanda,catarrhal conjunctivitis,Parisheka.

\section{INTRODUCTION}

Eye is considered as the most important and delicate sense organ of human body. The eye, an organ of sight is of utmost importance as far as ones existence is concerned. Eyes hold special status among all the senses. Eyes are the most precious gift of the God to the living beings. Good vision is crucial for social and intellectual development of a person. So to protect this organ is not only a necessity but also a responsibility of every individual.

The detailed description of Vataj abhishyanda according to its etiology, signs, symptoms and treatment is given in sushrut samhita.(6/5)

\section{Simple Allergic Conjunctivitis:}

It is the most common form of ocular allergy and it is hypersensitivity reaction to specific airborn antigens. It is an inflammation of the conjunctiva due to allergy. Basically it is urticarial reaction. Sub acute catarrhal conjunctivitis ; It is a common type of bacterial 
conjunctivitis. Common causative bacterias are staphylococcus, kochweeks bacillus, pneumococcus and streptococcus. The clinical features are discomfort and foreign body sensation due to engorgement of blood vessels, photophobia, mistiness of vision due to a thin layer of discharge of mucous on the the cornea, sticking together of lid margin during sleep due to the discharge, conjunctival type of congestion, chemosis of conjunctiva and mild oedema of lids.

\section{Importance of Seka}

It is exclusive ayurvedic treatment with least complications as it is used externally.If parisheka is given according to dosha condition, then it can even cure the balwan dosha. A good appreciation from patient is received.

\section{MATERIALS AND METHODS}

MATERIALS:-

Drug information Parisheka will be given with kantakari mula siddha dugdha.The reference have been given in Sushrut samhita Ut.9/12

\section{1)Kantakari}

Rasa : Katu, Tikta,Guna : Laghu, Ruksha,Virya : Ushna,Vipaka : Katu,Doshaghnata: Vata, Kapha

Karma : Shothahara, Dipana, Pachana, Amadoshanashaka, Kanthya.

\section{2)Godugdha}

Ksira is a general term for the milk of any of the animals. But, in Ayurveda, Cow's milk is much appreciated for the therapeutic purposes.Here,.

\section{RASA PANCAKA :}

Rasa - Madhura,Guna - Guru, Snigdha,Virya - Sita,Vipaka Madhura,Prabhava - Not specified

\section{Group B drug information}

Ushnodaka-Without aushadhi dravya, when only water is boiled then it is called as Ushnodaka. Its use is done in koshna form.

\section{Standardization of drug}

1] Collection- Kantakari root was taken from reputed Ayurvedic drug selling store.

\section{2] Authentication and Standardization}

- Authentication and

standardization tests done in Pharmacy College of our institute.

\section{Preparation method}

Bharad of Kantakari Mula was collected from reputed shop from market. Authentification of drug was made in Department of Rasashastra \& Bhaishjya Kalpana of college.

Preparation of Kantakari mula Siddha Dugdha Parisheka.

For this research; sharangdhar's concept for preparation of ksirapaka was followed.In 1part of $\operatorname{drug}(50 \mathrm{gms}), 8$ parts milk(400ml), and 32parts $(1600 \mathrm{ml})$ water was added. The boiling continued till water get evaporated and milk alone remained i.e ksiravashesham i.e $400 \mathrm{ml}$.

\section{Procedure}

1] Kantakari mula bharad (50gms), milk(400ml) and water(1600ml) was taken in a container.

2] Heating was carried out at mandagni. 3] Mixture should be stirred.

4] When milk remained or water evaporates heating is stopped.

5] When mixture becomes sukhoshna (temp.upto $38^{\circ} \mathrm{C}$ ), it is

filtered through the muslin cloth and used.

For parisheka vidhi every day a fresh kwath was prepared according to requirement.

\section{METHODOLOGY:}

The whole study is divided into,

Conceptual study

Clinical study 


\section{CONCEPTUAL STUDY:-}

Detailed review of Ayurvedic and modern literature was carried out to know about the disease entity and treatment etc. and also information \& updates from internet websites related to this subject were taken.

\section{CLINICAL STUDY:-}

.Inclusion criteria:

1] Patient of age group 15-60 yrs.

2] Patient having symptoms of vataj abhishyanda.

3] Patient's irrespective of sex, educational status, socio-economical status, marital status, caste etc.

4] Patients willing for treatment.

\section{Exclusion criteria}

1] Patient having disease other than vataj abhishyanda

2] Patient having major eye problems like corneal ulcers etc

3] Any malignant condition of eye

4] Patient having systemic diseases like T.B., leprosy, diabetes mellitus.

Parameters of assessment

a) Nistodana (pain):

- Grade 0 : No pain.

- Grade I : Mild pain.

- Grade II : Moderate pain.

- Grade III : Severe pain. b)Sangharsha (foreign body sensation):

- Grade 0 : Absent

- Grade I : Occasional.

- Grade II : Persistent, do not disturb routine.

- Grade III : Routine work disturbance.

c)Shiroabhitapa (headache):

- Grade 0 : Absent

- Grade I : Occasional
- Grade II : Persistent, do not disturb routine

- Grade III : Routine work disturbance d) Shishirashruta (watering of eye): according to the wetting of schirmer paper.

- Grade 0 : $10-15 \mathrm{~mm}$

- Grade I : $15-20 \mathrm{~mm}$

- Grade II : $20-25 \mathrm{~mm}$

- Grade III : > $25 \mathrm{~mm}$

e) Raga (congestion) i)palpebral conjunctiva

- Grade 0 :no congestion

- Grade I: congestion with clear pattern of blood Vessels.

- Grade II : congestion with poorly visible pattern of Blood vessels.

- Grade III : velvety conjunctiva or loss of bloood Vessels pattern

\section{ii) Bulbar conjunctiva}

Grade 0 : no congestion

Grade I : muddy color conjunctiva.

- Grade II : congestion in palpebral aperture.

- Grade III : congestion

\section{Sampling Technique:}

The patients were selected irrespective of caste, creed, religion, income, sex, occupation etc.

Random sampling technique was adopted. Patients were divided into two groups i.e. Group A and Group B.

\section{Group A - Trial group}

1] Total 30 patients

2] These will be treated with kantakari mula siddha dugdha

parisheka for 400 vak matra in aparanha kala once daily for 5 days.

3] Each patient's follow up will be taken and clinical findings will be 
recorded in time period interval in shalakya OPD of Rugnalaya.

4] Mode of administration - Parisheka.

\section{Group B -Control group}

1] Total 30 patients

2] These will be treated with sukhoshna jala parisheka for $400 \mathrm{vak}$

matra in aparanha kala once daily for 5 days.

3] Each patient's follow up will be taken and clinical findings will be

recorded in time period interval in shalakya OPD of Rugnalaya.

RESULT

Effect of treatment on $15^{\text {th }}$ day
4] Mode of administration - Parisheka.

OVERALL ASSESSMENT OF THERAPY -

It was done on the basis, no. of patients relieved (i.e. score 'o') and not relieved (i.e. score not 'o') in all signs and symptoms on the $15^{\text {th }}$ day of treatment in both the groups. Then statistical analysis done and significance of difference between both groups was assessed by applying Chi-square test. .

\begin{tabular}{|l|l|l|l|l|l|l|}
\hline Groups & Relief & No relief & Total & $\begin{array}{l}\text { Relief } \\
\%\end{array}$ & $\chi^{2}$ & P \\
\hline $\begin{array}{l}\text { Trial } \\
\text { Group }\end{array}$ & 29 & 1 & 30 & 96.67 & \multirow{2}{*}{4.04} & $<0.05$ \\
\hline $\begin{array}{l}\text { Control } \\
\text { Group }\end{array}$ & 24 & 6 & $30^{R}$ & 80 & \\
\cline { 1 - 4 }
\end{tabular}

On $15^{\text {th }}$ day $96.67 \%$ patients got relief in Tria group and $80 \%$ patients got relief in Control group. Overall effect of Treatnentsin both the groups-

\begin{tabular}{|l|l|l|l|l|l|l|}
\hline Group & Relief & $\begin{array}{l}\text { No } \\
\text { Relief }\end{array}$ & Total & $\begin{array}{l}\text { Relief } \\
\%\end{array}$ & \multirow{2}{*}{$x^{2}$} & P \\
\hline $\begin{array}{l}\text { Trial } \\
\text { Group }\end{array}$ & 26 & 4 & 30 & 86.66 & & \\
\cline { 1 - 3 } $\begin{array}{l}\text { Control } \\
\text { Group }\end{array}$ & 16 & 14 & 30 & 53.33 & 7.93 & $<0.05$ \\
\cline { 1 - 5 } Total & 42 & 18 & 60 & & & \\
\hline
\end{tabular}

\section{Overall effect of treatment of both} groups-

These graph and diagrams shows, out of 30 patients of Vataj Abhishyanda 26 (i.e. $86.66 \%$ ) patients got relief in all signs and symptoms in Trial group and out of 30 of patients of Control group 16 (i.e. 53.33\%) patients got relief in all signs and symptoms of Vataj
Abhishyanda. By statistical analysis $X^{2}$ value is 7.93 which is higher than $p$ table value (3.84) at $5 \%$ level of significance. So, their is significant difference in both the treatment groups. Discussion

There was no side effect of Kantakari Mula Siddha Dugdha Parisheka although few patients told 
that there was mild burning sensation immediately after Parisheka, probably this was due to entry of drug into eye. . This was managed by asking patient to wash eye with luke warm water.

Probable mode of action of Kantakari Mula Siddha Dugdha Parisheka-

Topically applied ophthalmic drugs are primarily used for local effect and systemic absorption.In parisheka drug is poured as thin stream on closed eye lid of patient which cover whole region of eye.Due to its ushna guna, prasarana of srotas take place and due to its action shamana of vata dosha take place.

\section{Probable action of formulation}

Kantakari is having katu, tikta rasa, ushna veerya and katu vipaka, where as dugdha having madhura rasa, sheeta virya and madhura vipaka.

Toda is Vata predominant condition. The freshly prepared kantakari mula siddha dugdha is having Koshna properties. Due to this property it probably causes Shamana of the vitiated Vata Dosha. Kantakari is having warm potency which pacifies vata dosha and there by pain i.e. it is useful in management of diseases having their origin Vata and along with milk which is having snigdha, guru property, madhura vipaka helps in pacifying vata dosha and performs ropana action.

Sangharsha is Vata predominant condition and it is due to Khara Guna. Kantakari along wid dugdha which is having snigdha guna has soothing effect and must be responsible for relieving foreign body sensation.

Also shiroabhitapa is caused by vitiated vata and due to ushna veerya of kantakari subsides it. Watering of eye caused by vitiated vata is reduced by ushna veerya and katu vipaka. Katu rasa has shoshan action, thus decreases watering of eye.

As netra is sthana of Alochak pitta and raga( redness) is observed due to increase in pitta i.e alochak pitta dushti is present, ushna veerya of kantakari and its katu vipaka causes pittavardhana but it is counteracted by madhura rasa and sheeta veerya of dugdha and thus causes pittashamana and thus might have decreased redness of eye.

\section{REFERENCES}

AYURVEDIC:-

1. Sushruta Samhita by Maharshi Sushruta with Ayurved Tattva Sandipika Commentary by Kaviraj Dr.Ambikadatta Shastri. Chaukhamba Sanskrit Sansthan, Varanasi. 16th Edition, 1997.

2. Sushruta Samhita Dalhana Comm. Nibandhasangraha, Ed. By Vd. Yadavaji Trikamji Acharya \& Narayana Ram Acharya, Chaukhamba Surbharati Prakashan, Varanasi, 2008.

3. Ashtang Hridaya of Vagbhatta with Sarvang Sundari commentary by Pt.Kashinath Shastri. Krishnadas Academy. 1st Edition.

4. Charaka Samhita with Hindi commentary, by K. N. Shashtri and G.M.Chaturvedi, Chaukhambha Vidyabhavan, Varanasi. 22nd Edition.

5. Ashtang Sangraha of Vriddha Vagbhata by Vaidya Ravidutta Tripathi, Chaukhamba Sanskit Prakashan. 2nd Edition, 1992

6. Madhava Nidana with 'Madhukosha' Sanskrita comm. By Shrivijayarakshita \& Shrikanthadatta and 'Vidyotini' Hindi Comm. by Shri Sudarshana Shashtri, edited by Prof. Yadunandana Upadhyaya. Chaukhambha Sanskrita Bhavan, Varanasi, 31st edition. 
7. Sharangadhar Samhita by Dr.Shailaja Shrivastav, Chaukhamba Orientalia Varanasi. 3rd Edition.

8. Shri. Bhavmishra with hindi Commentary by Pt. Shri. Bramhashankar Mishra, Chaukhamba Sanskrit Sansthan. 4th Edition1977.

9. Yogratnakar with Vidyotini Hindi Commentary by Vaidya Laxmi Pati Shashtri, Chaukhamba Sanskrit Series, Varanasi. 8th Edition.

10. Dravyaguna Vidnyan by Prof.P.V.Sharma. Chaukhamba Bharati Academy, Varanasi. 14th Edition 1993.

11. By Indradev Tripathi, Krishnadas Academy, Varanasi. 2nd Edition 1998.

12. By Prof. P.V.Sharma, Chaukhambha Orientalia, Varanasi. 2nd Edition.

13. By Sharma S. N. \& Hindi commentary by Shastri K. N., Motilal Banarasi Das publication, Delhi, 2004.
14. By Shri Vagbhattacharya, Hindi commentary by Kulkarni D.A., Meharchand Laxmandas publication, New Delhi, 1998.

15. Dr. Dhingari Laxmanchari, published by Chaukhamba Sanskrit Pratisthana, Delhi. 1st edition, 2005.

16. Shanthakumari P. K., Published by author. 1st edition, 2002.

17. Kanski, Butterworth Heinemann Elsevier Publication. 6th Edition, 2007.

18. Khurana A. K. New Age International Pvt. Ltd. New Delhi. 4th Edition, 2007.

19. Silhota and Tandon, Reed Elsevier India Private Limited. 20th Edition, 2007.

20. Myron Yanoff and Duker, MOSBY Elsevier. 2nd Edition.

21. K. D. Tripathi, Jaypee Brothers. 5th Edition, 2003.

22. L.C.Dutta, Jaypee Brothers. 3rd Edition 2005.

Cite article:

EFFECT OF KANTAKARI MULA SIDDHA DUGHDA PARISHEK IN THE

MANAGEMENT OF VATAJ ABHISYANDA

Supriya Gangaram Patil

Ayurlog: National Journal of Research in Ayurved Science- 2018; (6)(6): 1-6 